\title{
MODEL KEPEMIMPINAN ETNIS TIONGHOA DI JAWA BARAT (SURVEI PADA PERHIMPUNAN FUQING DI JAWA BARAT)
}

\author{
Mulyani \\ Universitas Katholik Parahyangan - Bandung \\ Email: zhong.yannie@gmail.com
}

\begin{abstract}
The purpose of this research is to developing a leadership model of Tionghoa Ethnic in West Java, through a survey at Fuqing Association in West Java. The study was using a purposive sampling technique in selecting 4 (four) Fuqing Association in West Java, in Bandung, Bogor, Cianjur and Sukabumi. A purposive sampling also applied in selecting respondents. A Collecting Data Technique was using a questionnaires and interviews. An Exploratory Factor Analysis and Confirmatory Factor Analysis were used to analyzing Tionghoa's Ethnic leadership model in West Java. Exploratory Factor Analysis was used to examine a research model consists of 8 (eight) leadership dimension. A confirmatory factor analysis with partial least square method was used to re-examine a result models. The results of research is a West Java Tionghoa ethnic leadership models, namely Confucius Sunda Leadership Model. A Confucius Sunda Leadership Model describes a charismatic leader figure which protecting, leads people, assisting and encourage his followers to achieve an organization's vision and mission together. A Confucius Sunda Leadership Model has its contribution in developing a leadership theory.
\end{abstract}

Keywords: Tionghoa ethnic leadership, Confucius Sunda Leadership Model, Confucius Values, Sundanese Wisdom Values, Fuqing Association.

Abstrak: Penelitian ini bertujuan untuk membangun model kepemimpinan etnis Tionghoa Jawa Barat dengan menggunakan survei yang dilakukan pada Perhimpunan Fuqing di Jawa Barat. Penelitian ini menggunakan teknik pemilihan sampel secara purposif untuk memilih 4 (empat) Perhimpunan Fuqing di Jawa Barat yaitu Bandung, Bogor, Cianjur dan Sukabumi. Pemilihan sampel responden juga dilakukan secara purposif Teknik pengumpulan data yang digunakan adalah kuisioner dan wawancara. Untuk menganalisis model kepemimpinan etnis Tionghoa Jawa Barat dilakukan dengan menggunakan analisis faktor ekploratori dan analisis faktor konfirmatori. Analisis faktor Ekploratori dilakukan untuk menguji model penelitian yang terdiri atas 8 dimensi kepemimpinan. Analisis faktor konfirmatori dilakukan untuk menguji kembali model yang dihasilkan dengan menggunakan metode partial least square. Berdasarkan hasil penelitian ini model kepemimpinan etnis Tionghoa Jawa Barat diberi nama Model Kepemimpinan Konfusius Sunda. Model Kepemimpinan Konfusius Sunda ini menggambarkan sosok pemimpin berkarisma yang melindungi dan menjaga dengan penuh kasih sayang sambil membimbing, mengarahkan, menumbuhkan kesadaran kepada bawahannya untuk bersama-sama mencapai visi dan misi organisasinya. Model Kepemimpinan Konfusius Sunda ini menjadi kontribusi bagi perkembangan teori kepemimpinan.

Kata Kunci: Kepemimpinan Etnis Tionghoa, Model Kepemimpinan Konfusius Sunda, Nilai-nilai Konfusius, Nilai Kearifan Lokal Sunda, Perhimpunan Fuqing. 


\section{PENDAHULUAN}

Teori kepemimpinan yang populer saat ini dapat dibedakan dalam dua mazhab yaitu : Kepemimpinan Barat dan Kepemimpinan Timur. Teori kepemimpinan yang berkembang saat ini, lebih mengacu pada teori kepemimpinan Barat, sedangkan teori kepemimpinan timur tergolong baru dan sangat terbatas. Padahal, seperti kita ketahui bahwa kepemimpinan dipengaruhi oleh budaya, dimana budaya ini juga turut andil dalam membentuk persepsi individu dan kelompok terhadap pemimpin dan kepemimpinan. Penelitian yang dilakukan Vilkinas et al (2009) misalnya, menunjukkan bahwa budaya dan perbedaan institusi mempengaruhi secara signifikan variabilitas dalam perilaku kepemimpinan (Vilkinas et al., 2009). Dengan demikian, teori kepemimpinan Barat tentunya akan kurang aplikatif jika diterapkan secara serta merta dalam organisasi yang berbudaya Timur, salah satunya seperti di Indonesia.

Chinese Leadership merupakan salah satu teori kepemimpinan yang mereperesentasikan budaya timur. Antusias penelitian terhadap manajemen dan organisasi Chinese sebagai salah satu representasi dari kepemimpinan timur nampaknya mulai tumbuh, di mana penelitian terkini berfokus pada kepemimpinan Chinese. Kepemimpinan Chinese dengan nilai-nilai budayanya nampak semakin diminati (Taormina, 2007). Salah satu yang melatarbelakangi antusias ini adalah kesuksesan organisasi atau perusahaanperusahaan Chinese khususnya mereka yang sudah menetap di negara lain (Chinese Overseas). Kesuksesan Chinese Overseas yang signifikan dalam bisnisnya memunculkan pemikiran akan pentingnya memahami etos kerja mereka, mekanisme kerja mereka, terutama adalah cara-cara, perilaku maupun sifat-sifat dan gaya kepemimpinan yang mereka gunakan.

Chinese Overseas merupakan sebutan Internasional yang ditujukan pada orangorang yang masih memiliki silsilah keturunan Chinese yang hidup dan menetap di negara lain secara permanen.Di Indonesia, Chinese Overseas disebut dan diakui secara Nasional sebagai etnis Tionghoa. Penggunaan istilah Tionghoa ini diatur dengan Keputusan Presiden Nomor 12 Tahun 2014 Tentang Pencabutan Surat Edaran Presidium Kabinet Ampera nomor SE-06/Pres.Kab/6/1967, tanggal 28 Juni 1967, yang mengatur mengenai pengunaan istilah Tionghoa untuk orang maupun komunitas Tionghoa menggantikan istilah Tjina/China/ Cina. Di wilayah Asia termasuk Indonesia, Chinese Overseas dan perusahaan-perusahaannya banyak yang memegang peranan penting di mana mereka seringkali merajai dunia bisnis dan perekonomian. Berdasarkan data terbaru yang diambil dari Forbes (2015), Indonesia's 50 Richest, diketahui bahwa hampir keseluruhan dari 50 (lima puluh) besar orang terkaya di Indonesia adalah Chinese Overseas atau etnis Tionghoa (Forbes, 2015).

Konfusius merupakan warisan budaya yang mendominasi orang-orang Tionghoa, termasuk etnis Tionghoa di Indonesia. Di Indonesia sendiri, ajaran Konfusius ini masih dijalankan oleh orang-orang Tionghoa baik dalam lingkup pergaulan sosial maupun dalam organisasi bisnis mereka. Hal ini terlihat jelas dari adanya prinsip family centerness dan kolektivisme yang masih dipegang erat oleh masyarakat Tionghoa. Trust 'kepercayaan' menjadi faktor dominan bagi mereka dalam menjalankan relasi bisnis dan pekerjaan dimana terdapat kecenderungan untuk mengutamakan mempekerjakan keluarga terdekat dan kecenderungan berkelompok sesuai dengan marga ataupun asal daerah mereka. Sistem kerja sama yang mereka yakini yaitu guanxi atau kongsi, menekankan pada kerjasama 
dalam membangun relasi yang baik. Jejaring sosial menjadi suatu yang penting dalam lingkup organisasi, yang diyakini mampu meningkatkan keberhasilan

Etnis Tionghoa adalah etnis yang memiliki kemelekatan yang kuat dengan negara asalnya yaitu Tiongkok. Mereka pada umumnya meyakini memiliki keterikatan yang kuat dengan budayanya (Wah, 2010) dan memiliki keyakinan bahwa masa depan perekonomian mereka bergantung pada kokoh dan kuatnya negara China. Di negara manapun mereka tinggal dan memegang kewarganegaraannya, mereka tetap mengidentifikasikan diri mereka sebagai orang Chinese dan seringkali merasa "more Chinese" daripada mereka yang tinggal di Tiongkok. Mereka memiliki keterikatan emosional yang sangat kuat dengan negara China, terutama dari sisi nilai-nilai Konfusius. Keterikatan emosional yang kuat antara etnis Tionghoa dengan negara asalnya (Tiongkok) dan budayanya memberikan pengaruh dalam praktek keorganisasian dan manajerial. Dalam bidang kepemimpinan, kepemimpinan etnis Tionghoa dipengaruhi nilai-nilai Konfusius, sebagai fondasi utama dari kepemimpinan Chinese (Wah, 2010). Nilai-nilai Konfusius ini begitu melekat dalam diri etnis Tionghoa dan diwariskan dari generasi ke generasi.

Disisi lain, budaya setempat dimana seseorang tinggal diyakini akan memberikan pengaruh dan mempengaruhi perilaku dan pembentukan karakter dari seseorang. Demikian halnya dengan etnis Tionghoa yang telah menetap hingga beberapa generasi, tentunya sedikit banyak akan dipengaruhi oleh budaya setempat. Demikian pula dalam hal kepemimpinan. Etnis Tionghoa di Indonesia tentunya tidak dapat dilepaskan dari budaya lokal dan lingkungan sekitarnya. Sesuai dengan kontek di mana penelitian ini diselenggarakan maka budaya Sunda adalah representasi budaya lokal, dimana etnis Tionghoa menetap di Tatar Priyangan. Salah satu falsafah Sunda yang terkenal yang menjadi nilai kearifan lokal masyarakat Sunda adalah Silih Asah, Silih Asih dan Silih Asuh. Nilai kearifan lokal ini menjadi bagian dari kehidupan etnis Sunda, termasuk dalam hal kepemimpinan dan persepsi kepemimpinan.

Seperti yang telah dibuktikan melalui berbagai penelitian mengenai kepemimpinan (Vilkinas et al., 2009) bahwa kepemimpinan dipengaruhi oleh budaya, maka logis bahwa budaya dalam hal ini adalah nilai-nilai Konfusius dan budaya lokal Sunda turut andil dalam membentuk persepsi individu (Tionghoa) dan kelompok (Tionghoa) terhadap pemimpin dan kepemimpinan etnis Tionghoa. Persepsi individu dan/atau kelompok (Tionghoa) terhadap kepemimpinan etnis Tionghoa hanya bisa diperoleh melalui organisasi yang memiliki nilai otentik ketionghoan yang tinggi yaitu organisasi yang memiliki keanggotaan yang homogen (dalam hal ini etnis Tionghoa). Organisasi yang dirasakan mewakili nilai otentik tersebut adalah organisasi berbasis etnis, yaitu organisasi kedaerahan Tionghoa. Organisasi Kedaerahan ini memiliki nilai yang penting dalam kehidupan etnis Tionghoa. Organisasi Kedaerahan merupakan suatu klan yang memiliki ikatan cukup kuat dan penting karena merupakan organisasi yang dibentuk berdasarkan pada asal daerah dan leluhur. Seperti juga dijelaskan oleh Dawis (2010) bahwa etnis Tionghoa memiliki adat penghormatan terhadap leluhur, seperti membersihkan makam, membakar dupa dan bagi mereka yang cukup berada biasanya memiliki ruang leluhur berupa tempat untuk menyimpan papan berukirkan nama leluhur yang dihormati, kebiasaan ini terus diulang dari generasi ke generasi dan diperkuat dengan ikatan keluarga, rumah dan tempat dan juga merupakan kebiasaan yang memperkokoh kesetiaan terhadap marga dan desa mereka (Dawis, 2010). Hal-hal yang telah disebutkan diatas mendasari dipilihnya organisasi Kedaerahan Tionghoa sebagai objek penelitian diantara banyaknya 
organisasi Tionghoa lainnya seperti INTI (Indonesia Tionghoa) atau PSMTI (Paguyuban Sosial Marga Tionghoa) dan sejenisnya.

Penelitian ini meneliti kepemimpinan etnis Tionghoa Jawa Barat pada organisasi kedaerahan di Jawa Barat yang selanjutnya akan dirumuskan dan dibangun menjadi sebuah model kepemimpinan. Secara spesifik, penelitian ini dilakukan di organisasi kedaerahan Perhimpunan Fuqing di Jawa Barat. Poin utama yang ingin dicari jawabannya melalui ini adalah: Seperti apakah model kepemimpinan etnis Tionghoa Jawa Barat pada Perhimpunan Fuqing di Jawa Barat.

\section{KAJIAN TEORI}

Pemahaman Mengenai Istilah Chinese Overseas. Tiongkok merupakan negara terbesar di Asia di mana penduduknya banyak yang merantau dan menetap di negara lain. Penduduk asli Tiongkok yang merantau dan menetap di negara lain tersebut secara Internasional disebut sebagai Chinese Overseas/Overseas Chinese. Istilah Chinese Overseas dan Overseas Chinese merupakan dua istilah yang sering dipakai dalam literatur. Kedua istilah tersebut lazim digunakan dalam penelitian dan merujuk pada objek yang sama. Secara terminologi, dijelaskan oleh Pan (2009) dalam The Chinese Overseas Encyclopedia bahwa Overseas Chinese berasal dari kata Huaqiao di mana Hua merujuk pada "Hua people" atau"Chinese" dan qiao berarti "to stay away from home somewhere temporary". Bila diterjemah secara bebas berarti orang Chinese yang tinggal jauh dari rumah (Tiongkok) untuk sementara waktu (Pan, 2009). Hal ini berbeda dengan faktanya di mana mereka (Chinese Overseas) tinggal secara permanen di negara barunya. Hal ini pula yang melatarbelakangi beberapa peneliti untuk memilih menggunakan istilah Chinese Overseas. Istilah Chinese Overseas memiliki padanan kata dalam bahasa Mandarin Huaren yang artinya adalah Chinese people. Chinese Overseas didefinisikan sebagai penduduk keturunan Tiongkok yang hidup diluar negara Tiongkok yang menetap secara permanen di negara tersebut (Loy, 2012; Pekerti, 2008; Yeung, 2006).

Chinese Overseas yang pada faktanya menetap secara permanen di suatu negara baru, tetap memiliki ikatan emosional yang kuat dengan negara asalnya yaitu Tiongkok. Dalam kehidupan kesehariannya mereka tetap menjaga nilai-nilai "Chinese" mereka. Mereka seringkali lebih Chinese daripada mereka yang tinggal di Tiongkok sendiri. Mereka masih tetap mempertahankan budaya Chinese dalam kehidupan mereka, salah satunya adalah budaya Konfusius. Chinese Overseas ini tetap terhubung dan saling terkait oleh kesamaan budaya dan warisan filosofi mereka. Secara ekstrim dapat dikatakan bahwa Chinese Overseas adalah seperti gurita raksasa yang kaki-kakinya menjangkau seluruh dunia. Mereka secara virtual membentuk negara tanpa batas 'a Nation without border' (Loy, 2012). Secara ringkas, Chinese Overseas dapat didefinisikan sebagai berikut: Chinese Overseas adalah orang-orang keturunan/peranakan Tiongkok atau mereka yang memiliki darah Chinese/Tionghoa yang tinggal dan menetap secara permanen di luar negara Tiongkok dan memiliki kewarganegaraan dari negara yang bersangkutan.

Chinese Overseas di Indonesia (Etnis Tionghoa). Layaknya Chinese Overseas di berbagai negara lain, Chinese Overseas di Indonesia memegang peranan penting dan memiliki kesuksesan dalam bidang ekonomi. Banyak diantaranya yang dikenal sebagai tokoh-tokoh fenomenal yang kisah hidupnya ditulis dan dijadikan inspirasi. Mereka, Chinese Overseas yang menetap di Indonesia ini lebih dikenal dengan sebutan etnis Tionghoa. Kapan dan di mana tepatnya etnis Tionghoa pertama kali datang ke Indonesia, 
hingga saat ini belum diketahui secara pasti. Diyakini bahwa etnis Tionghoa telah mengenal kepulauan Nusantara jauh sebelum Masehi, kendati demikian belum terdapat catatan sejarah yang dapat memberikan gambaran secara pasti kapan, dimana, bentuk hubungan seperti apa yang pernah terjalin dan apa kegiatan mereka saat itu. Dalam catatan sejarah Indonesia, Kedatangan etnis Tionghoa pada masa Indonesia kuno adalah dalam rangka perdagangan yang dikenal dengan jalur sutra (silk road). Kendati diyakini bahwa etnis Tionghoa telah ada di Indonesia jauh berabad-abad sebelumnya, Era kedatangan etnis Tionghoa sebagai Chinese Overseas dalam catatan sejarah diawali pada masa dinasti Ming, yaitu pelayaran yang dilakukan Zheng He beserta awaknya pada awal abad ke-15 (lima belas), yang kemudian menetap di Semarang, Tuban dan Lasem. Migrasi Chinese Overseas yang signifikan terjadi pada sekitar akhir abad ke-19 (sembilan belas) ke sejumlah wilayah di Indonesia, khususnya Jawa (Lim dan Mead, 2011). Mereka yang bermigrasi sebagian besar berasal dari Tiongkok Tenggara. Mereka meninggalkan Tiongkok untuk mencari kehidupan yang lebih baik, di mana saat itu krisis sedang melanda Tiongkok yang berdampak pada kehidupan pertanian.

Secara jumlah berdasarkan fakta dan perkembangannya hingga saat ini tidak diketahui secara pasti jumlah etnis Tionghoa di Indonesia. Berdasarkan pada data sensus tahun 2000, etnis Tionghoa di Indonesia jumlahnya hanya sekitar $0.9 \%$ saja dari keseluruhan etnis yang ada di Indonesia. Mereka sebagaian besar berada di pulau Jawa, Kalimantan dan sekitarnya. Data Overseas Chinese Population by Country tahun 2011 menunjukkan jumlah Etnis Tionghoa di Indonesia sekitar 8.010.000 orang (Overseas Chinese Affairs Council, 2011). Faktanya banyak etnis Tionghoa Indonesia yang enggan untuk mengakui diri mereka Tionghoa. Hal ini berkaitan dengan maraknya isu SARA dan diskriminasi terhadap etnis Tionghoa di Indonesia.

Secara umum Tionghoa Indonesia berasal dari suku Han, mereka berasal dari wilayah selatan Tiongkok. Kelompok yang terbesar dalam Tionghoa Indonesia adalah mereka yang berasal dari Hokkian. Termasuk dalam golongan ini adalah mereka yang memiliki leluhur yang berasal dari daerah Fujian. Mereka banyak menempati wilayah Jawa dan Madura. Tionghoa Hokkian ini merupakan salah satu kelompok yang terbesar jumlahnya dan tatanan bahasanya banyak diserap dalam bahasa Indonesia (Liem dan Mead, 2011).

Nilai-nilai Konfusius Sebagai Akar Budaya Tionghoa. Nilai-nilai Konfusius sebagai akar dari budaya Tionghoa yang diimplementasikan dalam berbagai sisi kehidupan etnis Tionghoa baik pergaulan sosial, organisasi, bisnis dan menejemen telah banyak ditulis dan disepakati oleh para peneliti kebudayaan Chinese dan Chinese Overseas (Wah, 2010; Lin, 2010). Dalam bidang leadership, hasil penelitian Wah (2010) mengungkapkan bahwa ajaran dasar dari Konfusius telah menyatu dengan gaya kepemimpinan Chinese yaitu moral character, human-heartedness, human relationship, lifelong learning dan moderation.

Memahami ajaran Konfusius sebagai aspek perilaku sosial adalah sesuatu yang mendasar untuk memahami orang-orang Tionghoa. Hal ini karena Konfusius merupakan warisan budaya yang mendominasi orang-orang Tionghoa (Lin, 2010). Salah satu contoh yang mencolok dari ajaran Konfusius dalam kehidupan etnis Tionghoa adalah pentingnya keluarga. Bagi penganut Konfusius keluarga adalah pusat dari semua hubungan. Mereka memiliki kecenderungan menaruh kepentingan keluarga diatas kepentingan bisnis dan lainnya. Bagi orang Tionghoa keluarga memegang peranan penting. 
Filosofi Konfusius menurut Chuang (2012) dapat digambarkan dalam 4 prinsip berikut ini:

1. Hubungan hirarki untuk mencapai stabilitas. Prinsip utama dari ajaran Konfusius adalah stabilitas dari struktur sosial berdasarkan pada hirarki yang dikenal sebagai lima hubungan (wulun): individu-hukum, ayah-anak, suami-istri, teman-teman, tuamuda. Manusia dapat hidup bahagia hanya jika stabilitas sosial tercapai melalui hubungan hirarki tersebut.

2. Pengembangan diri secara terus menerus. Pengembangan diri dapat terwujud melalui pembelajaran yang menekankan pada etika dan kecerdasan kognitif. Belajar yang dimaksud disini adalah suatu proses yang tidak pernah ada akhirnya dalam kehidupan seseorang lebih dari sekedar kebutuhan akan kemampuan baru atau pendidikan formal, sama halnya dengan konsep life-long learning.

3. Hubungan yang harmonis dengan orang lain. Bagian dari tujuan dalam pengembangan diri adalah untuk mencapai harmonisasi hubungan.Untuk memelihara harmonisasi hubungan seseorang harus: menyadari dirinya sebagai seorang anggota keluarga, mengatasi individualitasnya, menjaga "wajah" orang lain dengan menghargai martabat dan gengsinya. Dalam menjaga hubungan yang harmonis, guanxi memegang peranan yang penting, guanxi merupakan jaringan sosial yang sensitif untuk memelihara hubungan personal dan sosial yang efektif.

4. Perilaku kebajikan yang humanis. Dalam ajaran Konfusius bakti memiliki prioritas tertinggi melebihi pembelajaran. Bakti merupakan bentuk tanggungjawab keluarga, moralitas personal bagi keharmonisan keluarga.(Chuang, 2012)

Kepemimpinan Konfusius. Kepemimpinan Konfusius adalah kepemimpinan Chinese dalam kerangka nilai Konfusius. Kepemimpinan Konfusius dikembangkan dari perpektif Konfusius atau norma-norma yang diajarkan dan dipraktekkan selama kurang lebih 3000 tahun. Kepemimpinan Konfusius menurut Cheung dan Chan (2008) memiliki sejumlah karakteristik yang mencerminkan Kebajikan, Pembelajaran, Harmonisasi, Peraturan, Inovasi, dan dasar pemikiran Konfusius (Cheung dan Chan, 2008). Dari lima prinsip utama dalam Konfusius yaitu: ren, chun $t z u$, li, te, wen, menurut Hill (2006) kepemimpinan Tionghoa dipengaruhi 3 prinsip Konfusius yaitu te (mengacu pada kekuasaan oleh aturan laki-laki (power of man rules)), ren (menekankan pada hubungan yang ideal antar individu yang didasarkan pada kebajikan, humanis, dan cinta kasih), dan yi (mengacu pada aturan-aturan yang berkaitan dangan perilaku yang baik, sesuatu yang seharusnya dilakukan) (Hill, 2006). Menurut Cheng (2011) terdapat 10 karakteristik kepemimpinan berdasarkan nilai-nilai Konfusius klasik yaitu: pemahaman yang mendalam mengenai ren (kemanusiaan), menjalankan aturan dengan kebajikan, memiliki kebajikan (kekuatan untuk membangkitkan kesadaran dan mempengaruhi orang lain untuk melakukan hal yang sama), mampu menegaskan keyakinan individu dan kolektif dalam menjalankan kebijakan dan berelasi, interaksi dan hubungan timbal balik berdasarkan pada instrospeksi diri dan kepedulian terhadap orang lain, hadir sebagai contoh yang menginspirasi dan membentuk kepercayaan dan rasa hormat, adil dan berbudi, mampu menyelesaikan konflik dan menyesuaikan diri dengan lingkungan baru, memiliki keberanian dalam menghadapi krisis dan bertahan untuk mendidik penerus yang potensial, praktek pengunduran diri yang bijak (Cheng, 2011). Karakter kepemimpinan masa kini yang mencerminkan ideologi Konfusius menurut McDonald (2011), adalah: (1) Terlihat tenang, personal yang rendah hati yang memperoleh penghargaan berdasarkan 'sense of ; relationship' yang dipandang dari perspektif orang lain adalah kebapakan dan spiritual; (2) 
Pemimpin yang pluralistik dan holistik yang mencari kesempatan untuk meningkatkan hubungan yang harmonis yang mengintegrasikan seluruh fraksi yang ada; (3) Sementara mereka bekerja keras dan ambisius, mereka tidak terlihat agresif; (3) Mereka akan mengarahkan dan mencapai hasil sambil memproyeksikan atmosfir kesabaran. (McDonald, 2011)

Nilai budaya Sunda: Silih Asih, Silih Asah, Silih Asuh. Konsep Silih Asih, Silih Asah, Silih Asuh adalah kearifan lokal yang juga menjadi falsafah hidup masyarakat Sunda yang melekat dan dijadikan pegangan, landasan dalam hidup bermasyarakat. Silih dalam bahasa Indonesia dapat diartikan atau disubtitusi dengan kata "saling". Secara harafiah silih asih, silih asah dan silih asuh menurut suryalaga (2010) dapat diartikan sebagai berikut:

1. Silih asih adalah rasa atau tingkah laku yang menunjukan kasih sayang yaitu saling pikanyaah, saling pikaasih, saling pikaheman. Silih asih berarti saling mengasihi, saling mencintai satu sama lainnya, memberi perhatian, afeksi, dan kasih sayang, satu sama lain menunjukkan kepeduliannya, memberikan apa yang dibutuhkan dengan tulus;

2. Silih asah diartikan sebagai saling mempertajam, secara lebih luas Silih Asah dapat diartikan saling berbagi ilmu, saling mengajarkan keahlian dan pengetahuan, saling membangun kemahiran, dan masih banyak makna positif lainnya;

3. Silih asuh mengandung makna membimbing, mendidik, memelihara, saling mengingatkan, saling mengawasi dan menjaga yang dibarengi dengan rasa sayang dan kasih. Konsep silih asuh dapat diartikan sebagai saling melindungi, saling mendampingi, saling menyayangi, saling menghormati, saling menghargai yang akan melahirkan rasa tentram penuh dengan getaran silaturahmi (Suryalaga, 2010).

Secara harafiah Silih Asih, Silih Asah, Silih Asuh dapat diartikan sebagai saling mempertajam diri, saling mengasihi, dan saling memelihara. Berdasarkan pada makna dan nilai-nilai filosofinya, kata silih bukan hanya untuk menunjukkan kesadaran untuk berbagi, melainkan juga kesadaran bahwa apa yang dikerjakan dan dihasilkan adalah juga menjadi kepentingan bersama, mencerminkan kesadaran untuk maju dan bertumbuh kembang bersama (Hartanto, 2009). Dalam budaya Sunda seorang pemimpin yang baik dan ideal adalah patut memiliki sikap silih asih, silih asah, dan silih asuh. Kepemimpinan yang Silih Asih, Silih Asah, Silih Asuh adalah kepempimpinan yang menunjukkan sikap dan perilaku yang penuh kasih sayang, penuh kepedulian terhadap bawahannya, sangat menghargai pentingnya pengetahuan, berorientasi untuk terus meningkatkan kemampuan dan pengetahuan yang dimiliki pribadinya dan bawahannya, yang menjadikan kasih sayang sebagai landasan untuk mengayomi, menjaga, dan penuh kepedulian terhadap anggota organisasi dan organisasinya untuk melahirkan rasa percaya dan saling menghargai, yang tujuan besarnya adalah untuk memberikan manfaat bagi kesejahteraan anggota, organisasi dan lingkungannya

Naskah Sunda kuno Buhun Kabuyutan Ciburuy yang berasal dari abad 16 masehi mencantumkan tuntunan moral atau pedoman bagi seorang pemimpin dalam melaksanakan tugas dan kepemimpinannya agar berhasil dan dicintai, baik oleh rakyat maupun oleh bawahannya. Seorang pemimpin ideal dalam budaya Sunda menurut naskah tersebut harus berpegang teguh kepada prinsip astaguna (delapan kearifan) sehingga kepemimpinannya berjalan selaras, baik dan harmonis (Suryani, 2012). Delapan kearifan tersebut adalah Animan (lemah lembut), Ahiman (tegas), Mahiman (berwawasan luas), Lagiman (gesit/cekatan/trampil), Prapti (tepat sasaran), Prakamya (ulet/tekun), Isitwa 
(jujur), Wasitwa (terbuka untuk dikritik). Karakteristik kepemimpinan Sunda tertulis dalam naskah Siksa Kandang Karesihan dimana pemimpin yang baik adalah pemimpin yang dalam dirinya melekat karakter pangimbuhning twah dan dituntut untuk memiliki sifat dasa prasanta (Suryani 2012). Dasa Prasanta atau sepuluh pedoman adalah tuntutan yang harus dimiliki serta dilaksanakan oleh seorang pemimpin dalam rangka membina serta memimpin bawahannya. Dasa Prasanta ini kaidahnya berpijak kepada kuantitas dan kualitas hubungan antar manusia (human relationship) namun tidak dalam kondisi hubungan majikan-buruh yang kaku dan otoriter dimana proses komunikasinya menggunakan silih asih, silih asah, dan silih asuh. Pangimbuhning twah menitikberatkan pada aspek-aspek karakter yang harus dimiliki seorang pemimpin yaitu berupa karakter positif yang harus dipertahankan dan dikembangkan.

\section{METODE}

Organisasi Kedaerahan Tionghoa yang dipilih sebagai objek penelitian ini adalah Perhimpunan Fuqing di Jawa Barat yang dipilih secara purposif meliputi 4 (empat) kota yaitu Bandung, Bogor, Cianjur dan Sukabumi. Perhimpunan Fuqing merupakan organisasi yang dibentuk sebagai wadah bagi etnis Tionghoa yang memiliki leluhur yang berasal dari Fujian tepatnya kota Fuqing. Perhimpunan Fuqing merupakan organisasi sosial yang bergerak dalam bidang sosial dan kemanusiaan. Perhimpunan Fuqing ini umumnya dalam rangka melestarikan dan memperkenalkan budaya dan adat istiadat Tionghoa menyelenggarakan pendidikan bahasa Mandarin, pelatihan seni musik Tiongkok dan pelatihan tari Tiongkok. Perhimpunan Fuqing ini juga biasanya aktif menyelenggarakan kegiatan-kegiatan yang bersifat sosial seperti bakti sosial dan kegiatan sosial lainnya diantaranya adalah memberikan bantuan bagi masyarakat yang kurang mampu, menyelenggarakan pengobatan gratis, dan tanggap dalam memberikan bantuan bagi korban bencana.

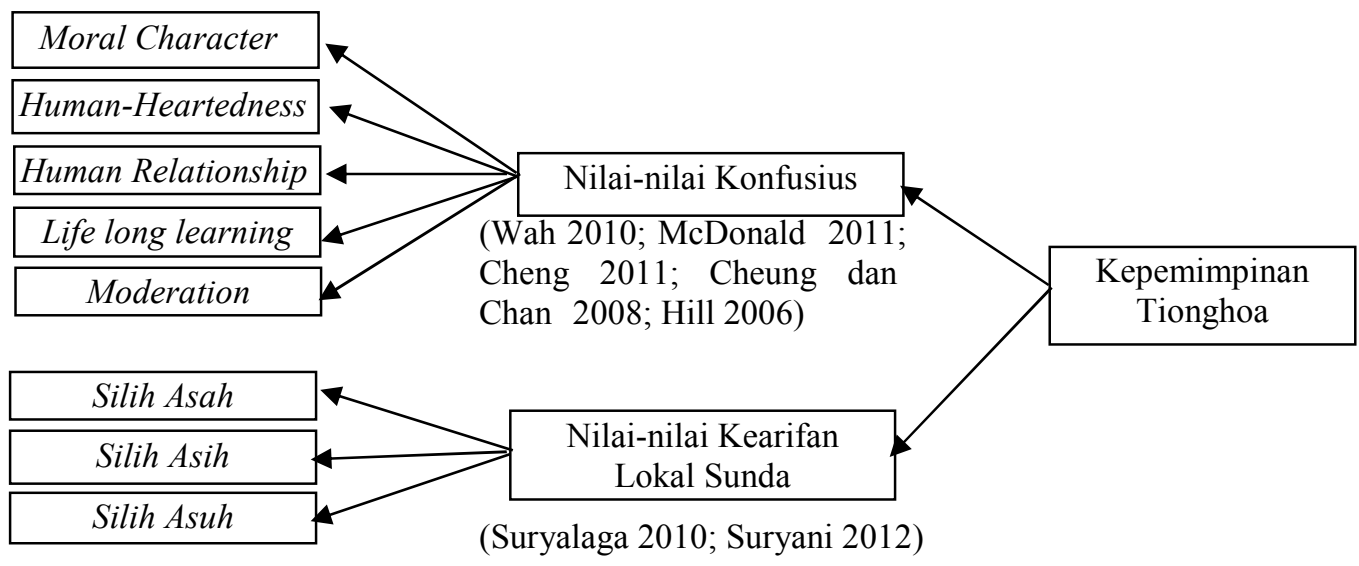

Gambar 1. Model Penelitian

Responden yang dipilih sebagai sampel dalam penelitian ini adalah pengurus yang aktif pada Perhimpunan Fuqing di Bandung, Bogor, Cianjur dan Sukabumi. Berdasarkan pada penilaian dari Ketua, Wakil Ketua, dan/atau Narasumber kunci dari masing-masing Perhimpunan Fuqing diketahui bahwa total jumlah pengurus yang aktif adalah 121 (seratus dua puluh satu). Kuisioner dalam penelitian ini digunakan untuk mengumpulkan data berkaitan dengan persepsi dari pengurus aktif pada Perhimpunan Fuqing terhadap 
kepemimpinan yang dijalankan oleh Ketua Harian/Fungsionaris di Organisasi Kedaerahan Perhimpunan Fuqing di Jawa Barat. Kuisoner pada penelitian ini, menggunakan skala sikap yaitu skala yang digunakan untuk mengukur sikap, persepsi, dan pendapat responden. Secara lebih spesifik, skala sikap yang akan digunakan adalah skala likert dengan menggunakan 7 (tujuh) kategori respon yaitu: SL (Selalu), SS (Sering Sekali), CS (Cukup Sering), M (Mungkin), KK (Kadang-kadang), HTP (Hampir Tidak Pernah), TP (Tidak Pernah). Penelitian ini adalah untuk membangun sebuah model kepemimpinan yang baru yaitu model Kepemimpinan etnis Tionghoa dengan memperhatikan dan menekankan pada nilai-nilai budaya sebagai unsur yang mempengaruhi persepsi individu terhadap kepemimpinan, oleh karena itu seperti yang dijelaskan oleh Harrington (2009) bahwa analisis faktor ekploratori dapat digunakan sebagai langkah pertama ekplorasi dalam membangun sebuah pengukuran dan kemudian dilanjutkan dengan analisis faktor konfirmatori untuk mengkonfirmasi struktur faktor yang telah diidentifikasi melalui analisis faktor ekploratori (Harrington 2009), demikian pula yang dilakukan dalam penelitian ini. Dalam penelitian ini terlebih dulu akan digunakan analisis faktor ekploratori untuk menguji model proposisi penelitian dan dilanjutkan dengan analisis faktor konfirmatori untuk menguji model penelitian yang dihasilkan dari hasil pengujian pertama. Analisis data dalam penelitian ini dilakukan dengan bantuan piranti lunak IBM SPSS 20 dan Smart PLS 3.0.

Pada gambar 1, yang merupakan model penelitian ini, kepemimpinan Tionghoa terdiri atas 8 (delapan) dimensi kepemimpinan, yaitu 5 (lima) dimensi yang berasal dari nilai Konfusius: moral character, human heartedness, human relationship, life long learning, moderation dan 3 (tiga) dimensi yang berasal dari nilai kearifan lokal Sunda: silih asih, silih asah, silih asuh.

\section{HASIL DAN PEMBAHASAN}

Profil Responden. Responden dalam penelitian ini adalah pengurus aktif pada Perhimpunan Fuqing Bandung, Bogor, Cianjur dan Sukabumi yang secara keseluruhan berjumlah 121 (seratus dua puluh satu) responden. Responden yang terlibat dalam penelitian ini memiliki usia diatas 40 (empat puluh) tahun, usia responden termuda adalah 43 (empat puluh tiga) tahun dan responden tertua berusia 74 (tujuh puluh empat) tahun. Responden dalam penelitian ini hampir seluruhnya menguasai bahasa Mandarin dan seluruh responden yang ada mampu memahami dan berbicara bahasa Sunda dengan baik dimana pada umumnya mereka gunakan dalam keseharian mereka.

Hasil Pengujian dengan Analisis Faktor Ekploratori. Pada penelitian ini kesepakatan nilai variabel manifes yang dianggap memiliki korelasi yang tinggi antar variabelnya dan dianggap signifikan menjadi bagian dari variabel laten tertentu diputuskan dengan syarat nilai bobotnya $>0.6$. Proses analisis faktor ekploratori dilakukan dalam 4 (empat) tahap analisis, dimana setiap analisisnya melibatkan 2 (dua) buah variabel laten secara bersamaan. Tahap pengujian ini berdasarkan pada latar belakang konsep penelitian dimana diyakini bahwa suatu budaya dimana seseorang tinggal akan mempengaruhi persepsinya terhadap kepemimpinan (Vilkinas et al., 2009), maka akan dilihat apakah persepsi etnis Tionghoa terhadap nilai-nilai Konfusius dan cara memaknai nilai-nilai tersebut dipengaruhi oleh nilai-nilai budaya setempat, dan demikian juga sebaliknya. Tahap pengujian ini juga dilakukan berdasarkan pada kedekatan konseptual dari variabel 
manifesnya. Bila dicermati secara konsep, kendati berlatar budaya yang berbeda, variabel laten nilai-nilai Konfusius memiliki kedekatan makna dengan variabel laten nilai-nilai lokal Sunda. Hal ini karena keduanya merupakan ajaran dan pedoman perilaku dan sikap hidup yang berdasarkan pada nilai-nilai etika dan moral. Khusus untuk variabel Moderation dan Human Relationship, kedua variabel tersebut dianalisis secara bersamaan dengan pertimbangan bahwa variabel manifes dari kedua variabel tersebut bila ditelaah masih memiliki kedekatan korelatif yang diperkirakan mempengaruhi satu sama lain. Hasil pengujian analisis faktor ekploratori pada setiap tahapnya dapat dilihat pada Tabel 1.

Hasil Pengujian Tahap 1: Analisis Faktor Ekploratori Variabel Moral Character dan Variabel Silih Asuh. Pada pengujian ini ditentukan jumlah faktor yang dibentuk adalah 2 (dua) faktor, sesuai dengan konsep awal bahwa memang terdapat 2 (dua) faktor yang diujikan, sehingga pengelompokan faktor pada saat pengujian dilakukan tetap menggunakan 2 (dua) faktor yang hasilnya akan digunakan untuk memberikan kepastian, variabel manifes mana yang akan mengelompok kedalam faktor yang merepresentasikan Moral Character dan mana yang mengelompok dalam faktor Silih Asuh.

Pada pengujian pertama diketahui masih terdapat variabel yang memiliki MSA $<0.5$ yaitu variabel moral character no.16 dan silih asuh no.12 untuk memenuhi syarat kelayakan variabel maka kedua variabel tersebut disisihkan dari analisis. Setelah menyisihkan 2 (dua) variabel yaitu mor16 dan asuh12, Hasil KMO and Bartlett's menunjukan nilai yang $0.760(>0.5)$ dengan signifikansi yang dihasilkan dari Bartlett's Test of Sphericity sebesar 0.000 (>0.05). Dengan hasil di atas, maka dapat dikatakan bahwa variabel dan sampel yang digunakan memungkinkan untuk dilakukan analisis lebih lanjut.

Sesuai logika analisis faktor yaitu bahwa variabel-variabel yang cenderung mengelompok akan memiliki korelasi yang cukup tinggi dengan variabel lainnya, maka akan kita lihat pada 2 (dua) kelompok variabel dibawah ini dimana pada logikanya bahwa variabel-variabel yang berasal dari moral character seharusnya akan mengelompok pada 1(satu) kelompok yang sama, demikian pula variabel-variabel dari silih asuh akan mengelompok pada 1 (satu) kelompok lainnya. Untuk mengetahui variabel-variabel tersebut masuk kedalam faktor 1 (satu) atau 2 (dua) (yang dalam hal ini belum ditentukan mana yang merupakan kelompok variabel moral character atau kelompok variabel silih asuh), dapat dilihat dari nilai loading factor-nya. Dengan menggunakan hasil output dari SPSS, didapatkan hasil nilai loading factor dari setiap variabel manifes pada 2 (dua) kelompok variabel. Proses selanjutnya adalah memilah variabel berdasarkan nilai loading factor-nya sesuai cut off value yang telah ditentukan sebelumnya yaitu $>0.6$. Secara otomatis variabel yang memiliki nilai loading factor yang tidak memenuhi kriteria akan disisihkan.

Berdasarkan pada hasil dari analisis faktor ekploratori yang telah dilakukan, sejumlah variabel telah terpilih dan terkelompokan sedang sebagian lagi tersisihkan. Hasil analisis faktor ekploratori menunjukan perubahan pengelompokan variabel manifes. Bila dicermati hasil faktor dari variabel manifes sebagian besar mengelompok pada faktor 1 (satu) dimana seharusnya faktor 1 (satu) ini-bila dilihat dari hasil faktor yang adamerepresentasikan Moral Character. Dengan banyaknya variabel manifes dari silih asuh yang turut mengelompok menjadi satu dengan variabel manifes dari moral character, maka perlu dicari nama baru untuk faktor 1 (satu) tersebut. Faktor baru yang terbentuk dari gabungan variabel Moral Character dan Silih Asuh akan diberi nama baru yang merepresentasikan keduanya yaitu Moral Mengayomi. Mengayomi dalam bahasa 
Indonesia berarti melindungi. Pemimpin yang menerapkan Moral Mengayomi adalah sosok pemimpin yang memiliki karakter moral yang menumbuhkan kepercayaan dan simpati dari bawahannya sehingga mampu memberikan kenyamanan, membuat orangorang yang dipimpinnya merasa nyaman, aman dan terlindungi. Bila diilustrasikan adalah seperti pohon beringin yang kokoh yang memberikan keteduhan, rasa sejuk, nyaman kala terik matahari. Sedangkan untuk faktor 2 (dua), juga terdapat variabel manifes dari Moral Character yang berpindah dan mengelompok dengan variabel manifes dari Silih Asuh, dengan demikian faktor 2 (dua) juga perlu diberi nama baru yang representatif karena variabel silih asuh yang baru ini secara otentik tidak lagi sama dengan variabel silih asuh sebelumnya yang memuat nilai-nilai asli Sunda . Variabel Silih Asuh yang baru yang didalamnya terdapat juga Moral Character, akan penulis beri nama baru yaitu Moralitas Silih Asuh. Pemimpin yang mengaplikasikan Moralitas Silih Asuh adalah sosok pemimpin yang menjaga dan mengasuh bawahannya dengan pola-pola pengasuhan yang menekankan moral dengan menunjukan sikap dan perilaku yang mencerminkan kualitas moral dari seorang pemimpin yang pantas dijadikan panutan.

Pada variabel manifes yang menjadi bagian dari Moralitas Silih Asuh, tampak bagaimana sosok pemimpin adalah sosok yang memiliki memiliki kerendahan hati sesuai dengan nilai Kesundaan, dimana orang Sunda senantiasa memiliki kesadaran bahwa dirinya hanya bagian kecil dari alam semesta (Rosidi 2010). Sikap kerendahan hati ini ditunjukan dengan mau mengakui keunggulan bawahannya dengan tidak segan mengungkapkan kekagumannya terhadap orang tersebut. Sosok pemimpin juga harus mampu menjadi kebanggaan bagi bawahannya, patut dijadikan contoh, memiliki kebajikan yang ditunjukan dengan memberikan perhatian kepada bawahannya baik secara moril dan materiil.

Hasil Pengujian Tahap 2: Analisis Faktor Ekploratori Variabel Human Heartedness dan Variabel Silih Asih. Human heartedness adalah karakteristik yang berasal dari nilai Konfusius yang menekankan pada aspek hati nurani manusia sebagai pedoman dalam bersikap dan berperilaku, sedangkan silih asih adalah karakteristik yang berasal dari nilai Sunda yang menekankan pada olah rasa, rasa asih atau kasih sayang sebagai pijakan dalam bersikap dan berinteraksi. Bila dianalisa secara konsep maka bisa didapati kedekatan rasa, makna dan hubungan dari kedua variabel tersebut.

Pengujian pertama yang dilakukan adalah melihat nilai MSA dari tabel Anti-Image Matrices, dimana hasil yang diinginkan adalah semua variabel memiliki MSA $>0.5$ yang artinya variabel dapat diprediksi dan dianalisis lebih lanjut. Adapun hasil yang diperoleh dari analisis adalah seluruh variabel yang ada telah memiliki MSA $>0.5$, dengan demikian tidak terdapat variabel yang tersisihkan pada uji kelayakan ini. Hasil KMO and Bartlett's menunjukan nilai yang $0.789(>0.5)$ dengan signifikansi yang dihasilkan dari Bartlett's Test of Sphericity sebesar 0.000 (>0.05), maka dapat dikatakan bahwa variabel dan sampel yang digunakan memungkinkan untuk dilakukan analisis lebih lanjut.

Sama halnya dengan pengujian sebelumnya, pada pengujian terhadap variabel human heartedness dan variabel silih asih ini penulis menentukan faktor yang terbentuk menjadi 2 (dua) faktor. Logika pengujiannya adalah variabel manifes yang merepresentasikan human heartedness akan memiliki kemelekatan yang tinggi dan mengelompok dalam 1 (satu) faktor, demikian juga variabel manifes dari silih asih akan mengelompok dan membentuk 1 (satu) faktor lainnya. 
Hasil analisis faktor ekploratori menunjukan terdapat sejumlah varibel manifes yang bertukar posisi yang semula merupakan manifes dari human heartedness menjadi silih asih, demikian pula sebaliknya. Secara konsep variabel manifes kedua variabel laten diatas disusun berlandaskan pada teori sebelumnya, namun pada faktanya penelitian ini menunjukan korelasi yang kuat yang membuat beberapa variabel mengelompok dengan variabel lainnya pada 2 (dua) faktor yang terbentuk. Fenomena ini dapat dianalisis dari sisi budaya sebagaimana diketahui bahwa budaya mempengaruhi persepsi seseorang terhadap kepemimpinan, maka logis nilai-nilai budaya Konfusius yang dianut oleh etnis Tionghoa telah berakulturasi dengan nilai-nilai lokal sehingga memunculkan suatu cara pandang baru dalam memaknai nilai-nilai Konfusiusnya, demikian juga nilai-nilai Konfusius sebagai core values yang dimiliki etnis Tionghoa telah mempengaruhi cara etnis Tionghoa memaknai nilai-nilai Kesundaan.

Hasil dari analisis faktor ekploratori pada faktor 1 (satu), bila dicermati lebih merepresentasikan kelompok manifes dari human heartedness, tampak pula bahwa sejumlah manifes yang berasal dari silih asih turut mengelompok pada faktor 1 (satu) tersebut. Bila dianalisis lebih lanjut, kita bisa melihat ternyata bahwa rasional, tidak egois, menghargai hasil karya bawahannya, tidak mencari popularitas pribadi dan mau berkorban materi, diklaim sebagai wujud dari praktek nilai-nilai Konfusius. Nilai loading ketiga pernyataan tersebut juga tinggi, hal ini menunjukan bahwa ketiga hal tersebut bagi etnis Tionghoa di Jawa Barat khususnya bagi Perhimpunan Fuqing sangat penting. Gambaran sosok pemimpin mereka adalah orang yang rasional, tidak egois, menghargai hasil kerja bawahannya, tidak mencari popularitas pribadi, dan mau berkorban secara materi. Ini sangat relevan dengan analisis dan hasil penelitian dilapangan dimana pemimpin yang dipilih dalam Perhimpunan Fuqing memiliki "keharusan" mampu secara finansial. Diharapkan dengan adanya sosok pemimpin yang mampu secara finansial, hal ini menunjukan mereka telah sukses dalam bisnisnya, yang berarti juga diharapkan dapat membawa dan memimpin perhimpunan dengan baik dan sukses pula. Tentu saja, kesuksesan secara finansial juga diperlukan agar seorang pemimpin dapat menjadi salah satu menyokong berbagai keperluan yang berkaitan dengan kebutuhan perhimpunan bila diperlukan. Sama halnya dengan ilustrasi pohon beringin, pohon beringin yang kokoh, besar, memiliki akar-akar yang panjang, daun yang rindang, barulah dapat mengayomi dan memberikan keteduhan. Seperti itu pula sosok pemimpin etnis Tionghoa, bila tidak rindang, tidak kokoh, maka tidak akan mampu menaungi anggota organisasinya, ketika banyak orang bernaung dibawahnya, bersandar pada batang dan dahannya, ia akan tumbang.

Mencintai, melayani dan kesabaran dinilai sebagai representasi nilai Kesundaan silih asih. Sebagaimana diketahui bahwa etnis Tionghoa adalah berawal sebagai etnis perantauan, jauh dari tempat asalnya, harus bertahan hidup dalam lingkungan yang cukup keras dengan berbagai kondisi politik di Indonesia, hal ini sewajarnya membentuk karakter dimana nilai-nilai ketegasan dan sedikit keras dalam mendidik anak-anak diperlukan. Demikian pula dalam berorganisasi, nilai-nilai kelembutan dinilai bukan bagian dari akar budaya mereka, tetapi tampaknya nilai-nilai kelembutan juga diterapkan dalam Perhimpunan Fuqing dan dianggap berasal dari budaya Sunda yang memang sudah dikenal bahwa orang Sunda adalah orang yang lemah lembut, sabar, mau melayani orang lain dan umumnya baik hati.

Melihat hasil analisis faktor ekploratori dimana kedua faktor yang terbentuk tidak lagi "murni" terdiri dari manifes dari masing-masing variabel asalnya, maka penulis akan 
memberikan nama baru bagi kedua faktor yang terbentuk yang dapat merepresentasikan nilai-nilai didalamnya. Untuk faktor 1 (satu) yang adalah berasal dari human heartedness akan diberi nama nurani welas asih. Nurani welas asih adalah Kepemimpinan yang dijalankan berdasarkan hati nurani sebagai pedoman sikap dan perilaku yang penuh kasih sayang yang ditunjukan dalam memperlakukan bawahannya. Sedangkan untuk faktor 2 (dua) yang berasal dari silih asih akan diberi nama silih asih humanistis. Silih asih humanistis adalah kepemimpinan yang dijalankan berdasarkan pada nilai-nilai kasih sayang yang dalam mengimplementasikan kasih sayang kepada bawahannya mengedepankan dan mengutamakan nilai-nilai kemanusiaan.

Hasil Pengujian Tahap 3: Analisis Faktor Ekploratori Variabel Life Long Learning dan Variabel Silih Asah. Inti dari life long learning adalah semangat belajar seumur hidup yang terus menerus mengatasi segala batasan diri, terus mengembangkan diri, terus memacu diri, dan tidak berhenti sampai pada tahapan diri sendiri melainkan meneruskan pancaran semangat tersebut kepada sekitar, pada orang-orang disekitarnya. Hal serupa, semangat yang hampir sama juga didapati pada silih asah, tidak berbicara pada durasi waktu, silih asah lebih menekankan pada saling memaknai untuk meningkatkan dan terus menerus saling mengembangkan diri dan kemampuan diri. Berdasarkan pada konseptualnya tersebut maka kedua variabel ini dianalisis secara serempak menggunakan analisis faktor ekploratori untuk menguji korelasi dari variabel manifesnya.

Hasil uji KMO and Bartlett's pada variabel-variabel dari life long learning dan silih asah menunjukan nilai yang $0.738(>0.5)$ dengan signifikansi yang dihasilkan dari Bartlett's Test of Sphericity sebesar $0.000(>0.05)$. Dari hasil yang diperoleh, maka dapat dikatakan bahwa variabel dan sampel yang digunakan memungkinkan untuk dilakukan analisis lebih lanjut.

Hasil faktor kedua variabel diatas menunjukan hal yang serupa dengan hasil faktor pada analisis sebelumnya, yaitu terjadi perpindahan kelompok manifes dari variabel life long learning dan silih asah. Dari hasil faktor nampak bahwa budaya Sunda memberikan pengaruh pada cara pandang etnis Tionghoa dalam memaknai life long learning, demikian pula sebaliknya, pemahaman etnis Tionghoa dalam memaknai nilai lokal Sunda juga dipengaruhi oleh nilai-nilai Konfusius sebagai akar budayanya. Hasil faktor ini juga menunjukan kemelekatan yang harmonis dimana makna silih asuh maupun makna life long learning bagi etnis Tionghoa telah saling berbaur.

Berdasarkan hasil diatas, life long learning bagi etnis Tionghoa pada Perhimpunan Fuqing dimaknai lebih dari sekedar pembelajaran diri terus menerus, tetapi juga dimaknai dengan lebih mendalam yaitu dengan adanya unsur pengendalian diri dan tidak serakah. Tidak serakah dan pengendalian diri ini memang berasal dari nilai budaya Sunda yang ternyata dimaknai oleh etnis Tionghoa sebagai bagian yang cukup penting dalam proses belajar. Dalam budaya Sunda sendiri terkenal ungkapan "ulah sagala hoyong diraup $k u s i k u$ " yang bila diterjemah secara harfiah "jangan segala ingin diambil dengan siku". Ungkapan ini mengajarkan orang untuk tidak menjadi serakah dalam hidupnya, seperti kita ingin mengambil semua hal dengan siku tangan, pada akhirnya semua jadi tidak dapat terambil hanya akan menjadi mubazir sehingga unsur pengendalian diri menjadi penting dalam mencegah diri menjadi orang yang serakah. Ternyata didalam pembelajaran terus menerus, etnis Tionghoa memaknainya dengan nilai Sunda tersebut, dimana memang ketika kita mempelajari hal baru atau segala hal di dalam hidup tidak dapat lepas dari proses, semua harus dilakukan secara bertahap, tidak dapat dilakukan secara sekaligus. 
Disinilah perlunya pengendalian diri untuk dapat bertahan dalam proses pembelajaran yang berkesinambungan dan terus menerus.

Silih asah dalam pandangan etnis Tionghoa di Perhimpunan Fuqing, menggambarkan sosok pemimpin yang pantas dijadikan panutan, dimana gambaran yang muncul adalah pemimpin yang memiliki pengetahuan dan keahlian diatas bawahannya, mampu mengatur dengan baik sekaligus memiliki kesabaran dalam membimbing. Keterbukaan yang berasal dari nilai Konfusius, ternyata dianggap sebagai gambaran dari kepemimpinan yang silih asah. Hal ini menunjukan bahwa unsur keterbukaan merupakan faktor yang dinilai penting dalam Perhimpunan Fuqing dimana pemimpinnya mau terbuka menerima kritik dan mau terbuka berbagi pengetahuan dengan bawahannya. Sesuai dengan karakteristik yang tercermin dalam manisfesnya maka untuk kelompok variabel pada faktor 1 (satu) yang merupakan kelompok manifes yang berasal dari silih asah, akan diberi nama keterbukaan dalam silih asah. Pemimpin yang memiliki keterbukaan dalam silih asah adalah pemimpin yang memiliki kualitas dan kesadaran diri untuk belajar sekaligus memiliki mentalitas seorang pendidik yang terbuka terhadap kritikan dan terbuka dalam membagi ilmunya.

Sedangkan untuk faktor 2 (dua) yang merupakan kelompok manifes dari life long learning akan diberi nama semangat belajar seumur hidup yang mawas diri. Sosok pemimpin yang mencerminkan semangat belajar seumur hidup yang mawas diri adalah pemimpin yang mendidikasikan kepemimpinannya untuk mendorong dan memotivasi orang lain untuk terus belajar dengan disertai kesadaran diri 'mawas diri' untuk mampu tetap bertahan dalam melalui tahapan-tahapan belajar sebagai sebuah proses untuk mencapai kebaikan.

\section{Hasil Pengujian Tahap 4: Analisis Faktor Eksploratori Variabel Moderation dan} Variabel Human Relationship. Moderation dan human relationship merupakan dua variabel yang sama-sama merupakan dimensi dari nilai-nilai Kepemimpinan Konfusius. Pada analisis faktor ekploratori ini keduanya dipasangkan berdasarkan pada pertimbangan bahwa manifes keduanya sama-sama berorientasi pada cara berinteraksi dengan sesama.

Hasil uji KMO and bartlett's pada variabel-variabel dari human relationship dan moderation menunjukan bahwa satu dari variabel human relationship harus disisihkan yaitu variabel HR2 karena nilai MSAnya $<0.5$. Hasil uji KMO and Bartlett's setelah variabel HR2 dikeluarkan dari analisis menunjukan nilai yang $0.709(>0.5)$ dengan signifikansi yang dihasilkan dari bartlett's test of sphericity sebesar $0.000(>0.05)$. Dengan hasil tersebut, maka dapat dikatakan bahwa variabel dan sampel yang digunakan memungkinkan untuk dilakukan analisis lebih lanjut.

Hasil analisis faktor eksploratori pada variabel moderation dan human relationship menunjukan hasil yang cukup mengejutkan dimana semua variabel manifes mengelompok menjadi satu. Hal ini menunjukan persepsi etnis Tionghoa di Indonesia terhadap dimensi Kepemimpinan Konfusius yang tercerminkan dalam moderation dan human relationship tidak dapat dipisahkan sebagai dua dimensi terpisah, namun keduanya merupakan suatu kesatuan. Tanggung jawab moral dalam masa sulit, perhatian terhadap kesejahteraan, memiliki pendekatan yang fleksibel, perkataan serta perilaku yang sejalan dan selaras, ternyata dipandang sebagai suatu kesatuan karakter. Etnis Tionghoa dalam Perhimpunan Fuqing memandang hubungan kemanusiaan sebagai sesuatu yang penting, dimana dalam menjalankan dan membina suatu hubungan yang baik unsur keselarasan dan keseimbangan menjadi faktor yang diperhatikan. Orang-orang Fuqing yang memiliki 
karakter dan intuisi kuat dalam bisnis, merupakan orang yang sangat memperhatikan pentingnya relasi, dengan adanya keselaran dan keharmonisan hubungan atau relasi dapat berjalan dengan baik. Relasi bagi orang Fuqing sangat penting, mereka menyadari bahwa kesuksesan tidak dapat dilakukan sendiri selalu memerlukan orang lain disekitar kita yang dapat membantu kita mencapai kesuksesan tersebut. Relasi yang baik akan menumbuhkan suatu hubungan kepercayaan yang dikenal dengan quanxi, dimana etnis Tionghoa sangat bergantung pada quanxi yang juga merupakan kunci kesuksesan bisnis mereka.

Berdasarkan hasil analisis faktor ekploratori terbentuk variabel baru yang yang merupakan gabungan dari moderation dan human relationship. Variabel baru tersebut akan diberi nama baru yang dapat merepresentasikan faktor baru tersebut yaitu Hubungan Kemanusiaan yang Selaras dan Harmonis. Sosok Pemimpin yang mencerminkan Hubungan Kemanusiaan yang Selaras dan Harmonis adalah pemimpin yang dalam menjalankan kepemimpinannya menekankan pentingnya membina relasi yang baik dengan memperhatikan keselarasan dalam perkataan dan perbuatan untuk mencapai suatu keharmonisan.

Hasil Pengujian dengan Analisis Faktor Konfirmatori. Pengujian analisis faktor konfirmatori terhadap model penelitian menggunakan PLS terdiri atas dua pengujian yaitu pengujian outer model dan pengujian inner model. Inner Model menggambarkan spesifikasi hubungan antara satu konstruk (variabel laten) dengan konstruk (variabel laten) lainnya, sedang outer model menggambarkan hubungan antara suatu konstruk (variabel laten) dengan indikator-indikatornya (variabel manifes). Berdasarkan pada modelnya maka analisis faktor konfirmatori pada penelitian ini adalah analisis faktor konfirmatori dua jenjang (second order confirmatory).

Hasil Uji Outer Model. Outer Model atau disebut juga sebagai model pengukuran menggambarkan hubungan antara variabel manifes atau indikator dengan variabel latennya. Pengujian Outer Model adalah untuk memastikan bahwa indikator sebagai alat ukur yang digunakan layak untuk dijadikan pengukuran (valid dan reliabel).

1. Hasil Uji Validitas. Menurut Ghozali (2008) suatu indikator dianggap valid jika memiliki loading 0.7 . Nilai loading 0.5 sampai 0.6 masih dapat diterima untuk penelitian yang sifatnya membangun sebuah model atau teori. Mengingat penelitian ini dapat dikatakan sebagai sebuah penelitian yang diawali dengan ekploratori untuk membangun sebuah model yang baru, maka nilai loading 0.5 dianggap layak, dengan demikian maka suatu indikator (variabel manifes) dinyatakan valid jika mempunyai loading factor di atas 0.5 terhadap konstruk (variabel laten) yang dituju.

Hasil pengujian menunjukkan bahwa nilai loading dari variabel manifes memberikan nilai di atas nilai yang disarankan (0.5) Hal ini dapat diartikan bahwa indikator yang dipergunakan dalam penelitian ini adalah valid yang berarti bahwa variabel manifes yang ada telah benar-benar merefleksikan variabel latennya dan telah benar-benar tepat untuk mengukur variabel laten yang direfleksikannya tersebut.

Hasil Uji Reliabilitas. Untuk menguji reliabilitas atau kehandalan indikator sebagai alat ukur digunakan pengujian dengan Chronbach Alpha dan Composite reliability dengan ketentuan sebagai berikut: (1) Chronbach Alpha (Ghozali, 2008). Suatu variabel dapat dikatakan reliabel apabila memiliki koefisien alpha lebih besar dari 0,6; (2) Composite reliability (CR) (Ghozali, 2008 ; Wetzels et al., 2009). Hasil CR akan menunjukkan nilai yang memuaskan jika nilainya di atas 0,7 . 
Hasil pengujian reliabilitas menggunakan Chronbach Alpha dan CR dari model penelitian ini menunjukan bahwa semua variabel laten baik first oder maupun second order memiliki nilai chronbach alpha diatas 0.6 dan CR diatas 0.7. Hasil tersebut menyatakan bahwa seluruh variabel laten memiliki reliabilitas yang baik dan memuaskan atau reliabel. Hal ini berarti bahwa seluruh indikator atau variabel manifes yang ada memiliki kehandalan dan konsistensi yang baik dimana bila digunakan berulangkali untuk mengukur variabel laten pada responden yang sama akan menunjukan hasil yang sama.

Hasil Uji Inner Model. Setelah melakukan rangkaian pengujian outer model, selanjutnya adalah pengujian terhadap inner model. Pengujian terhadap inner model dilakukan untuk memastikan bahwa model struktural yang dibangun robust dan akurat yang artinya model secara keseluruhan memiliki kecocokan dengan data atau mampu mencerminkan realitas dan fenomena yang ada dilapangan.

Pertama. Hasil pengujian Koefisien Determinasi ( $R$ Square). Pada pengujian inner model ini akan diuji besarnya kontribusi yang diberikan tiap variabel laten sebagai dimensi dari Kepemimpinan Konfusius Sunda terhadap Kepemimpinan Konfusius Sunda dengan melihat nilai koefisien determinasinya ( $R$ Square). Menurut Chin (1998b) dalam Urbach dan Ahlemann (2010), nilai $R$ Square $\left(\mathrm{R}^{2}\right)=0.67$ dikategorikan sebagai subtansial, $\mathrm{R}^{2}=$ 0.33 dikategorikan sebagai moderat dan $\mathrm{R}^{2}=0.19$ dikategorikan lemah (Urbach dan Ahlemann 2010). Sesuai dengan cut off value tersebut maka secara keseluruhan kontribusi variabel dalam model penelitian ini dikategorikan baik, dimana tidak terdapat variabel yang lemah. Dimensi Moral Mengayomi, Nurani Welas Asih, Hubungan Kemanusiaan yang Selaras dan Harmonis, Silih Asih Humanistis, Keterbukaan dalam Silih Asah memiliki kemampuan untuk menjelaskan Kepemimpinan Konfusius Sunda secara subtansial $(>0.67)$ yang artinya keseluruhan variabel tersebut sangat penting dan sesuai secara subtansinya dalam berkontribusi membentuk Kepemimpinan Konfusius Sunda ini. Sedangkan Semangat Belajar Seumur Hidup yang Mawas Diri dan Moralitas Silih Asuh memiliki kemampuan menjelaskan Kepemimpinan Konfusius Sunda secara moderat $(>0.33)$ yang artinya bahwa kedua variabel tersebut walaupun tidak mencapai subtansial namun masih memiliki kontribusi cukup penting dalam membentuk Kepemimpinan Konfusius Sunda.

Kedua. Hasil pengujian Goodness of Fit Model. Untuk menguji Goodness of Fit Model (GoF) atau kesesuaian model dalam PLS harus dikerjakan secara manual, sebagaimana disarankan dalam Wetzels et al (2009), dapat dihitung dengan rumus sebagai berikut:

$$
G o F=\sqrt{\overline{A V E} x \overline{R^{2}}}
$$

Dengan ketentuan nilainya menurut Wetzels et al (2009) sebagai berikut: GoF small $=0.1$, GoF medium $=0.25$, and GoF large $=0.36$

Berdasarkan pada hasil pengujian diketahui nilai GoF untuk model penelitian ini adalah 0.699 , dimana nilainya lebih besar dari cut off value 0.36 dengan demikian dapat disimpulkan bahwa model penelitian ini memiliki GoF yang besar yang berarti bahwa model struktural yang dibangun robust dan akurat, dengan kata lain model secara keseluruhan memiliki kecocokan dengan data atau mampu mencerminkan realitas dan fenomena yang ada dilapangan, dengan demikian hasil penelitian ini mewakili persepsi responden secara tepat, akurat dan terpercaya. 
Kepemimpinan Konfusius Sunda. Model Kepemimpinan Konfusius Sunda merupakan hasil dari penelitian ini. Model kepemimpinan ini merupakan sebuah model kepemimpinan yang baru, yang menjadi sumbangsih bagi perkembangan teori kepemimpinan di Indonesia khususnya di Jawa Barat. Model Kepemimpinan Konfusius Sunda ini sebagaimana dapat dilihat pada gambar 1 (satu), dibangun oleh 7 (tujuh) dimensi yang mewakili nilai-nilai etnis Tionghoa Jawa Barat. Selengkapnya dapat dilihat pada Gambar 2.

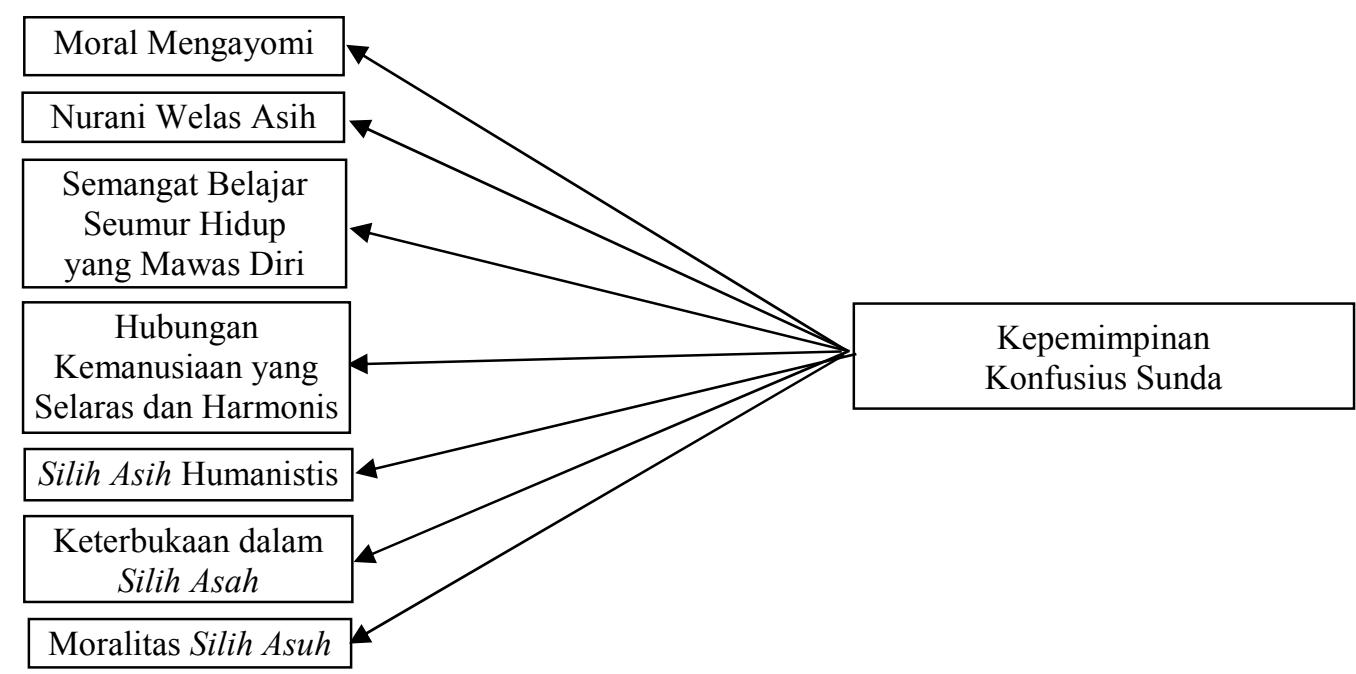

Gambar 2. Model Kepemimpinan Konfusius Sunda

Definisi dan Pemahaman mengenai Kepemimpinan Konfusius Sunda. Kepemimpinan Konfusius Sunda lekat dengan gambaran sosok pemimpin yang bila diilustrasikan adalah layaknya sebuah pohon beringin. Sosok yang dapat memberikan keteduhan, perlindungan kepada bawahannya, bahkan disaat-saat yang sulit sekalipun mampu dijadikan sandaran, tempat mencari keteduhan. Sosok yang memiliki "akar-akar" yang kuat yang dapat menjamin keberlangsungan organisasi dengan memberikan dukungan baik secara moril dan materil. Sosok pemimpin yang "cukup besar" untuk dilihat dari jauh sekalipun, memancarkan aura keteduhan, perlindungan, rasa aman kepada bawahannya yang memandang hubungan kemanusiaan sebagai sesuatu yang penting, dimana dalam menjalankan dan membina suatu hubungan yang baik unsur keselarasan dan keseimbangan menjadi faktor yang diperhatikan. Sosok pemimpin berkualitas yang cocok dan sesuai untuk dijadikan panutan, pemimpin yang memiliki sejumlah kualifikasi yang unggul yang memiliki pengetahuan yang luas dan mau membagikannya kepada bawahannya, mau maju bersama dan tetap rendah hati untuk menerima kritikan. Pemimpin juga dinilai memiliki kewajiban moral untuk mewujudkan rasa aman dan terayomi secara keseluruhan karena kenyamanan dan kesejahteraan anggota merupakan hal yang perlu diperhatikan dan dinilai penting dimana pemimpin dianggap merepresentasikan nilai-nilai moral yang sifatnya mengayomi seperti orang tua yang melindungi dan memberikan kenyamanan kepada anak-anaknya. Sesuai dengan penjelasan di atas, Kepemimpinan Konfusius Sunda didefinisikan sebagai berikut:

Kepemimpinan Konfusius Sunda adalah Kepemimpinan yang mengutamakan nilai-nilai moral yang mengayomi yang memiliki keterbukaan dalam silih asah, menjalankan prinsip-prinsip hubungan yang selaras dan harmonis berlandaskan pada nurani yang welas 
asih dan nilai silih asih humanistis, memiliki semangat belajar seumur hidup yang mawas diri serta memiliki moralitas silih asuh, yang memiliki tujuan untuk mewujudkan rasa aman, nyaman, dan terlindungi bagi seluruh bawahannya dan menciptakan kesadaran untuk maju dan bertumbuh kembang bersama.

Dimensi dan Karakteristik Kepemimpinan Konfusius Sunda. Berdasarkan hasil pengolahan data, analisis dan penemuan model, maka secara konsep Kepemimpinan Konfusius Sunda memiliki sejumlah karakteristik yang dibangun dari nilai-nilai Konfusius dan Sunda yang terdiri atas 7 (tujuh) dimensi yaitu:

1. Moral Mengayomi. Moral mengayomi merupakan dimensi dari Kepemimpinan Konfusius Sunda yang menggambarkan sosok pemimpin yang memiliki karakter moral yang menumbuhkan kepercayaan dan simpati dari bawahannya sehingga mampu memberikan kenyamanan, membuat orang-orang yang dipimpinnya merasa nyaman, aman dan terlindungi.

Moral mengayomi ini menggambarkan persepsi etnis Tionghoa terhadap sosok pemimpin yang memiliki nilai-nilai luhur. Seorang pemimpin dianggap sebagai sosok orang tua yang mengayomi sekaligus memiliki tanggung jawab. Selayaknya orangtua yang pasti tidak akan mencelakakan anaknya melainkan selalu memperhatikan perkembangan karakter dari anak-anaknya. sehingga dipercaya sepenuhnya baik perkataan maupun perbuatannya.

Karakteristik yang mencerminkan moral mengayomi ini adalah: Terpercaya, mengutamakan kebajikan, berwawasan, penuh perhatian, disiplin dan, berpengendalian diri menghargai orang lain, tegas, beretika, bijaksana, pelindung, menentramkan, simpatik

2. Keterbukaan dalam Silih Asah. Keterbukaan dalam silih asah merupakan dimensi dari Kepemimpinan Konfusius Sunda yang menggambarkan sosok pemimpin yang memiliki kualitas diri dan kesadaran untuk belajar sekaligus memiliki mentalitas seorang pendidik yang terbuka terhadap kritikan dan terbuka dalam membagi ilmunya.

Karakteristik Kepemimpinan Konfusius Sunda yang mencerminkan Keterbukaan dalam silih asah adalah:memahami semangat belajar, berwawasan luas, responsif, inovatif, telaten, jujur, terbuka terhadap kritikan, teliti

3. Silih Asih Humanistis. Silih asih humanistis merupakan dimensi dari Kepemimpinan Konfusius Sunda yang menggambarkan sosok pemimpin yang menjalankan kepemimpinannya berdasarkan pada nilai-nilai kasih sayang yang dalam mengimplementasikan kasih sayang kepada bawahannya mengedepankan dan mengutamakan nilai-nilai kemanusiaan. Kepemimpinan yang silih asih humanistis adalah kepemimpinan yang menunjukkan sikap dan perilaku yang penuh kasih sayang dan penuh kepedulian terhadap bawahannya, sebagai bentuk kesadaran untuk senantiasa memberikan manfaat bagi sesama dan lingkungannya.

Karakteristik Kepemimpinan Konfusius Sunda yang mencerminkan silih asih humanistis adalah: bersikap adil, humanis, menunjukkan kepercayaan, lemah lembut, rajin, sabar,menyadari hak dan kewajiban.

4. Nurani Welas Asih. Nurani welas asih merupakan dimensi dari Kepemimpinan Konfusius Sunda yang menggambarkan sosok pemimpin yang menjalankan kepemimpinannya berdasarkan hati nurani sebagai pedoman sikap dan perilaku yang ditunjukan dalam memperlakukan bawahannya.

Karakteristik Kepemimpinan Konfusius Sunda yang mencerminkan nurani welas asih adalah: mengutamakan kebajikan, penuh kepedulian, tidak egois, rasional, iklas dan mau berkorban. 
5. Hubungan kemanusiaan yang Selaras dan Harmonis. Hubungan Kemanusiaan yang selaras dan harmonis merupakan dimensi dari Kepemimpinan Konfusius Sunda yang menggambarkan sosok pemimpin yang dalam menjalankan kepemimpinannya menekankan pentingnya membina relasi yang baik dengan memperhatikan keselarasan dalam perkataan dan perbuatan untuk mencapai suatu keharmonisan. Hubungan kemanusiaan bagi etnis Tionghoa dipandang sebagai sesuatu yang penting dimana dalam menjalankan dan membina suatu hubungan yang baik unsur keselarasan dan keseimbangan menjadi faktor yang diperhatikan. Dengan adanya keselaran dan keharmonisan maka hubungan atau relasi dapat berjalan dengan baik.

Karakteristik Kepemimpinan Konfusius Sunda yang mencerminkan dimensi hubungan kemanusiaan yang selaras dan harmonis adalah: mengutamakan kepekaan sosial (renqing), mengutamakan prinsip hidup keselarasan.

6. Semangat Belajar Seumur Hidup yang Mawas Diri. Semangat belajar seumur hidup yang mawas diri merupakan dimensi dari Kepemimpinan Konfusius Sunda yang yang menggambarkan sosok pemimpin yang mendedikasikan kepemimpinannya untuk mendorong dan memotivasi orang lain untuk terus belajar dengan disertai kesadaran diri 'mawas diri' untuk mampu tetap bertahan dalam melalui tahapan-tahapan belajar sebagai sebuah proses untuk mencapai kebaikan. Semangat belajar seumur hidup yang mawas diri dimaknai lebih dari sekedar pembelajaran diri terus menerus, tetapi juga dimaknai dengan lebih mendalam yaitu dengan adanya unsur pengendalian diri dan tidak serakah, bahwa didalam pembelajaran terus menerus, ketika kita mempelajari hal baru atau segala hal di dalam hidup tidak dapat lepas dari proses, semua harus dilakukan secara bertahap, tidak dapat dilakukan secara sekaligus. Disinilah perlunya pengendalian diri untuk dapat bertahan dalam proses pembelajaran yang berkesinambungan dan terus menerus.

Karakteristik Kepemimpinan Konfusius Sunda yang mencerminkan dimensi semangat belajar seumur hidup yang mawas diri adalah:proaktif dalam belajar, tidak serakah, cekatan, multi talenta.

7. Moralitas Silih Asuh. Moralitas silih asuh merupakan dimensi dari Kepemimpinan Konfusius Sunda yang menggambarkan sosok pemimpin yang menjaga dan mengasuh bawahannya dengan pola-pola pengasuhan yang mengedepankan nilai-nilai moral yang ditunjukan melalui sikap dan perilaku yang mencerminkan kualitas moral dari seorang pemimpin yang pantas dijadikan panutan. Sosok pemimpin dalam moralitas silih asuh adalah sosok yang memiliki kerendahan hati, senantiasa memiliki kesadaran bahwa dirinya hanya bagian kecil dari alam semesta.

Karakteristik Kepemimpinan Konfusius Sunda yang mencerminkan dimensi moralitas silih asuh adalah: menjadi teladan, rendah hati, penuh pengertian.

\section{PENUTUP}

Kesimpulan. Berdasarkan hasil pengujian dan analisis yang telah dilakukan dalam penelitian model kepemimpinan etnis Tionghoa Jawa Barat yang dilakukan pada organisasi kedaerahan Perhimpunan Fuqing di Jawa Barat ini, secara umum kesimpulan yang dihasilkan adalah: Model kepemimpinan etnis Tionghoa Jawa Barat merupakan model kepemimpinan yang baru dan berbeda dengan kepemimpinan Chinese Overseas di negara lain dimana model ini dibangun dari nilai-nilai Konfusius dan nilai-nilai Sunda yang telah mengalami akulturasi. Model kepemimpinan yang baru ini, yang merupakan hasil penelitian ini diberi nama Model Kepemimpinan Konfusius Sunda. Model ini 
menjadi sumbangsih bagi perkembangan teori kepemimpinan di Indonesia khususnya di Jawa Barat. Kepemimpinan Konfusius Sunda ini merepresentasikan nilai-nilai kepemimpinan etnis Tionghoa di Jawa Barat yang didalamnya terkandung nilai-nilai Konfusius dan nilai-nilai Sunda yang telah saling beradaptasi, berakulturasi, membentuk sejumlah karakteristik kepemimpinan yang khas. Dalam nilai budaya Konfusius unsurunsur kebapakan adalah hal yang menonjol, dimana sosok pemimpin diidentikkan dengan kharisma seorang ayah sedangkan dalam budaya Sunda unsur keibuan yang lebih ditonjolkan, sehingga bila dihubungkan dengan model kepemimpinan ini, model kepemimpinan Konfusius Sunda ini adalah perpaduan nilai kebapakan dan keibuan yang secara kosmik menciptakan keselarasan dan keserasian.

Saran. Berhubungan dengan hasil penelitian ini yaitu Kepemimpinan Konfusius Sunda, penelitian berikutnya dapat melakukan penelitian lanjutan dengan mengujikan model Kepemimpinan Konfusius Sunda pada organisasi lain. Hasil penelitian tersebut mungkin akan memunculkan hasil yang memiliki unsur-unsur perbedaan bahkan dapat memunculkan suatu variabel baru yang akan dapat melengkapi model yang telah ada. Penelitian lebih lanjut juga dapat dilakukan dengan menguji hubungan Kepemimpinan Konfusius Sunda dengan efektifitas organisasi, komitmen organisasi, atau bahkan mencari bagaimana hubungan Kepemimpinan Konfusius Sunda ini trust dan loyalitas pada organisasi yang menerapkan jenis Kepemimpinan ini (tentunya setelah dilakukan penelitian awal yang menunjukkan bahwa kepemimpinan ini diterapkan pada organisasi tersebut).

\section{DAFTAR RUJUKAN}

Arkanudin.H., (2012) Akulturasi sebagai Mekanisme Perubahan Kebudayaan. ArkanBlog. (Online).(http://prof-arkan.blogspot.co.id/2012/04/akulturasi-sebagai-mekanismeperubahan.html diakses 31 Mei 2016)

Cheng, Chung-ying. (2011) "Confucian global leadership in Chinese tradition: classical and contemporary". Journal of Management Development, 30 ( 7): 647 - 662

Cheung, Chau-kiu., dan Chan, Andrew Chi-fai. (2008) "Benefits of Hong Kong Chinese CEO's Confucian and Daoist Leadership style". Leadership and Organization Development Journal. 29 (6): 474-503

Chuang, Szu-Fang. (2012) "Confucianization through globalization:evidence from the US", Journal of Chinese Human Resource Management. 3(2). 118-135

Dawis, Aimee. (2010) Orang Indonesia Tionghoa Mencari Identitas. Jakarta: Gramedia Pustaka Utama.

Forbes, (2015) “Indonesia's 50 Richest". (Online). (http://www.forbes.com/indonesiabillionaires/list/\#tab:overall, diakses 20 Juni 2016)

Ghozali, Imam.(2008) Structural Equation Model Metode Alternatif dengan Partial Least Square. Semarang: Badan Penerbit Universitas Diponegoro.

Harrington, Donna. (2009) Confirmatory Factor Analysis. New York: Oxford University Press.

Hartanto,Frans M.(2009) Paradigma baru Manajemen Indonesia: Menciptakan Nilai dengan Bertumpu pada Kebajikan dan Potensi Insani. Bandung: Penerbit Mizan

Hill, John.S. (2006). "Confusianism and the art of Chinese Management". Journal of Asia Business Study. 1-9. 
Lim, Hermanto dan Mead, David., (2011) "Chinese in Indonesia: A Background Study”. SIL Electronic Report March 2011. 1-37

Lin, Canchu. (2010) "Studying Chinese Culture and Conflict: a Research agenda". International Journal of Conflict Management. 21(1): 70-93.

Ling, Wenquan.,Chia, Rosina.c., Fang, Liluo. (2000) "Chinese Implicit Leadership theory". The Journal of Social Psycology. 140 (6): 729-739

Loy, Johnben Teik-Cheok. (2012). "Overseas Chinese family Business Research: a Comparative analysis". Journal of family business management. 2(1). 31-39

McDonald, Paul.(2011) "Maoism Versus Confucianism: Ideological Influences on Chinese Business Leaders". Journal of Management Development. 30 (7/8): 632-646

Overseas Chinese Affairs Council R.O.C, (2011) "Distribution of the Overses Chinese Population-Global Overseas Chinese Population statistics". (Online). (http://www.ocac.gov.tw/english/public/public.asp?selno=8889\&no=8889\&level=B, diakses 11 februari 2016)

Pan, L. (1999) The Encyclopedia of the Chinese Overseas. Cambridge: Harvard University Press.

Pekerti, Andre A. (2008) "The interdependent family-centric career: career perspective of the overseas Chinese in Indonesia". The Career Development Quarterly. 56 (4): 362377

Suryalaga, Hidayat, H.R. (2009) Kasundaan Rawayan Jati. Bandung: Yayasan Nur Hidayah

Suryani, Elis, (2012) "Konsep Figur Pemimpin dan Kepemimpinan yang terungkap dalam Skriptorium Naskah Sunda Buhun Kabuyutan Ciburuy". Simposium Internasional Pernaskahan Nusantara. Yogyakarta: Masyarakat Pernaskahan Nusantara

Taormina, R. J. (2008) "Interrelating leadership behaviors, organizational socialization, and organizational culture". Leadership \& Organization Development Journal, 29 (1): 85-102.

Vilkinas, Tricia., Shen, Jie., Cartan, Greg. (2009) "Predictors of leadership effectiveness for Chinese managers". Leadership\&organization Development Journal. 3 (6): 577 590

Wah, Sheh Seow. (2010) “Confucianisme and Chinese Leadership". Chinese management studies. 4 (3): 280-285

Wetzels, Martin., Odekerken-Schroder, Gaby.,Oppen, Claudia Van.(2009) "Using PLS Path Modeling for Assessing Hierarchical MIS Quarterly, 33 ( 1): 177-195

Yeung, H.W.C. (2006) "Change Construct MOdels: Guidelines and Empirical Illustration", and Continuity in Shoutheast Asian Ethnic Chinese Business". Asia Pacific J Manage. 23. 229-254 